RESUMO DE TESE

\title{
Efeitos do endolaser na safena magna para tratamento da doença venosa crônica
}

\section{Effects of endolaser on the greater saphenous vein in the treatment of chronic venous insufficiency}

Ricardo José Gaspar*

\begin{abstract}
Resumo
Objetivos: Avaliar os efeitos produzidos pelo endolaser na parede da veia safena magna insuficiente nas suas diferentes camadas. Determinar a evolução clínica dos pacientes, o índice de efeitos adversos e as complicações após a sua aplicação.

Métodos: Trinta e quatro membros inferiores de pacientes com doença venosa crônica, em estágio clínico CEAP (Clinical Etiology Anatomy Physiopathology) II a VI, com incompetência bilateral da junção safeno-femoral e da veia safena magna, confirmada por eco-Doppler, foram submetidos à ação do endolaser e acompanhados por um ano. Por sorteio, foi escolhido um lado no qual foi realizada crossectomia e ligadura da junção safenofemoral, seguida da retirada de um segmento de $3 \mathrm{~cm}$ da veia safena magna e posterior aplicação do laser na veia remanescente. Na veia safena magna contralateral, a retirada do segmento ocorreu após a aplicação do laser. A aplicação foi feita por meio de fibra condutora de $600 \mu$ introduzida por via endovenosa, ao nível da região perimaleolar por toda a veia safena magna, no sentido anterógrado, utilizando laser diodo com 15 watts de potência e $980 \mathrm{~nm}$ de comprimento de onda, de forma padronizada, guiada por eco-Doppler para monitoração em tempo real da termoablação da veiaalvo. Os segmentos retirados foram enviados para estudo histopatológico. Aqueles que foram retirados antes da aplicação do endolaser $(\mathrm{n}=17)$ se constituíram no Grupo Controle (G1), enquanto os que foram retirados após a aplicação do laser formaram o Grupo Laser (G2), sendo cada segmento controle do seu contralateral. Foram anotados os efeitos adversos e as complicações.

Resultados: A avaliação morfológica no Grupo G2 mostrou presença de edema, hemorragia, termocoagulação e trombose predominantemente na íntima. Inflamação e perfurações não foram observadas. A histomorfometria mostrou maior espessura, predominante na íntima, e aumento da concentração de colágeno nas três camadas no Grupo G2, estatisticamente significante comparado ao G1. Dos 34 membros tratados, 2,9\% apresentaram hiperpigmentação, hiperestesia, celulite e cordão fibroso, todos transitórios; em 8,8\%, constatou-se hipoestesia perimaleolar, transitória e sem repercussão clínica, e nenhum relato de trombose venosa profunda. Das 34 safenas fotocoaguladas, houve recanalização sem refluxo em uma delas no controle de um mês e 100\% de oclusão após seis meses e um ano mostrado pelo eco-Doppler.

Conclusão: Ablação utilizando endolaser 980 nm, combinado com crossectomia, eco-guiado em tempo real, promoveu fotocoagulação suficientemente controlada com oclusão imediata e prolongada da veia safena magna, de forma segura e eficaz, e configura-se como método terapêutico recomendável para o tratamento da doença venosa crônica.
\end{abstract}

Palavras-chave: Varizes; insuficiência venosa; veia safena/cirurgia; terapia a laser.

\begin{abstract}
Objectives: To evaluate the effects of endolaser on the wall of the insufficient greater saphenous vein. To determine the patients' clinical course, the rate of adverse effects and complications resulting from its application.

Methods: Thirty-four lower limbs of patients with venous chronic insufficiency, CEAP II to VI clinical score, and bilateral saphenofemoral junction and greater saphenous vein incompetence confirmed by duplex scan, underwent application of endolaser and followed for one year. Randomly, one side was chosen, in which crossectomy and ligature of the saphenofemoral junction were performed, followed by resection of a $3 \mathrm{~cm}$ segment of saphenous vein, and immediate application of endolaser in the remaining vein. In the contra-lateral saphenous vein, the segment resection was performed after endolaser application. The application was done through a $600 \mu$ optical fiber, introduced by endovenous access at the perimaleolar region, with
\end{abstract}

Tese de Doutorado desenvolvida na Escola Paulista de Medicina da Universidade Federal de São Paulo (EPM-Unifesp) pelo Programa de Pós-Graduação em Cirurgia e Experimentação, apresentada em 05.08.2010 por meio de defesa pública.

Orientador: Hélio Plapler

Co-orientador: Manuel Jesus Simões

Banca examinadora: Fausto Miranda Junior, Valter Castelli Junior, José Maria Soares Junior, Francisco Humberto Maffei

* Mestrado e Doutorado em Cirurgia pela EPM-Unifesp; Membro Titular da Sociedade Brasileira de Angiologia e de Cirurgia Vascular (SBACV); Chefe de Serviço de Cirurgia Vascular e Endovascular dos Hospitais Santa Catarina e São Camilo - Pompeia, São Paulo (SP), Brasil, Especialista em Cirurgia Vascular, Angiorradiologia e Cirurgia Endovascular pela SBACV/Associação Médica Brasileira (AMB), São Paulo (SP), Brasil.

Não foram declarados conflitos de interesse associados à publicação desta tese.

Submetido em: 05.11.10. Aceito em: 10.01.11

J Vasc Bras. 2011;10(1):81-82. 
antegrade progression up the length of the greater saphenous vein, with a $15 \mathrm{~W}$ power and $980 \mathrm{~nm}$ wavelength diode laser, in a standardized way, and color-Doppler guided for real time for monitoring of the target vein thermoablation. The removed segments were sent for histopathology study. The segments removed before endolaser application $(n=17)$ were the Control Group $(G 1)$, whereas the ones removed after endolaser application have formed the Laser Group (G2), and each segment was its contra-lateral control. Adverse effects and complications have been annotated.

Results: Morphological evaluation of Group G2 showed the presence of edema, haemorrhage, thermocoagulation, and thrombosis, predominantly in the intima. Inflammation and perforations were not observed. Histomorphometry showed increased thickness - predominant in the intima and also increased collagen concentration in all three layers of Group G2, statistically significant compared to G1. Out of the 34 limbs studied, $2.9 \%$ showed hyperpigmentation, hyperesthesia, cellulitis, and fibrotic cords - all of them temporary effects; in 8.8\%, it was observed transient perimaleolar hypoesthesia, without clinical consequences, and no case of deep venous thrombosis. Out of the 34 photocoagulated saphenous veins, there was 1 recanalization without reflux at the one-month follow-up visit and 100\% vein occlusion after 6 months and 1 year, as shown at the duplex scan.

Conclusion: Ablation using real time duplex scan-guided $980 \mathrm{~nm}$ endolaser combined with crossectomy has promoted properly controlled photocoagulation, with immediate and prolonged occlusion of the greater saphenous vein in a safe and efficacious way, and can be regarded as a recommended therapeutic method for the treatment of chronic venous insufficiency.

Keywords: Varicose veins; venous insufficiency; saphenous vein/ surgery; laser therapy.

Correspondência:
Ricardo José Gaspar
Rua Itapeva, 240, cj. 1.407 - Bela Vista
CEP 01332-000 - São Paulo, SP
E-mails: ricardojgaspar@terra.com.br; ricardojogaspar@hotmail.com

